\title{
UPAYA MENINGKATKAN HASIL BELAJAR MATEMATIKA SOAL CERITA MELALUI PENDEKATAN CONTEXTUAL TEACHING AND LEARNING (CTL) PADA SISWA KELAS III UPT. SD NEGERI 21 LIMO KAUM
}

\author{
BEN HARNIS \\ benharnis21@gmail.com
}

\begin{abstract}
Based on the observations of researchers at UPT. SD Negeri 21 Limo The students do not understand the story questions, and the learning is still carried out by the teacher conventionally. This results in low student scores, namely the achievement of the average score of students classically is 63.45. For this reason, the author through this study tries to improve student learning outcomes in solving story problems through the CTL approach. The purpose of this study was to describe the planning, form of implementation and learning outcomes of story problems through the CTL approach. Learning using the CTL approach has 7 steps, namely constructivism, finding, asking questions, the learning community, modeling, reflection, and actual assessment. The steps in the CTL approach are combined with the steps to solve story problems. This type of research is class action research, this research uses qualitative and quantitative approaches. While students who were taken as research subjects were all students of class III UPT. SD Negeri 21 Limo Kaum. The research data were obtained using tests, observations, interviews, and field notes. The research results from each cycle carried out in this study showed an increase in student learning outcomes from the initial test with an average of 63.45 and in the final action test cycle I the average student learning outcomes were 74.48 , while in the final action test cycle II average -The average score of students is 80.69. The results of the observations showed an increase in student activity in the learning process..
\end{abstract}

Keywords: Learning Outcomes, Mathematics, Contextual Teaching and Learning (CTL)

Abstrak: Berdasarkan pengamatan peneliti di UPT. SD Negeri 21 Limo Kaum siswa kurang memahami soal cerita, serta pembelajaran dilaksanakan oleh guru masih secara konvensional. Hal ini mengakibatkan nilai siswa rendah, yakni pencapaian nilai ratarata siswa secara klasikal adalah 63,45 Untuk itu penulis melalui penelitian ini mencoba meningkatkan hasil belajar siswa dalam menyelesaikan soal cerita melalui pendekatan CTL. Tujuan dari penelitian ini adalah untuk mendeskripsikan perencanaan, bentuk pelaksanaan dan hasil pembelajaran soal cerita melalui pendekatan CTL. Pembelajaran dengan menggunakan pendekatan CTL mempunyai 7 langkah, yaitu konstuktivisme, menemukan, bertanya, masyarakat belajar, pemodelan, refleksi, dan penilaian yang sebenarnya. Langkah pendekatan CTL tersebut dikombinasikan dengan langkah-langkah menyelesaikan soal cerita. Jenis penelitian ini adalah penelitian tindakan kelas (class action research), penelitian ini menggunakan pendekatan kualitatif dan kuantitatif. Sedangkan siswa yang diambil sebagai subjek penelitian adalah seluruh siswa kelas III UPT. SD Negeri 21 Limo Kaum. Data penelitian ini diperoleh dengan menggunakan tes, observasi, wawancara, dan catatan lapangan. Hasil penelitian dari setiap siklus yang dilaksanakan dalam peneitian ini terlihat peningkatan hasil belajar siswa dari tes awal dengan rata-rata 63,45 dan pada tes akhir tindakan siklus I rata-rata hasil belajar siswa 74,48, sedangkan pada tes akhir tindakan siklus II rata-rata nilai siswa yakni 80,69 . Hasil pengamatanpun terlihat \begin{tabular}{lll}
\hline EISSN 2657-0289 & Lembaga Penelitian dan Penerbitan Hasil Penelitian Ensiklopedia & 87
\end{tabular} 
peningkatan keaktifan siswa dalam proses pembelajaran. Penulis mengambil simpulan pada penelitian ini bahwa dengan menggunakan pendekatan CTL dapat meningkatkan hasil belajar siswa.

Kata kunci : Hasil Belajar.Matematika, Contextual Teaching and Learning (CTL)

\section{A. Pendahuluan}

Soal cerita merupakan salah satu materi pelajaran yang dapat mengembangkan proses berfikir siswa. Karena soal cerita dapat melatih siswa untuk berfikir kritis dan kreatif. Menurut Sumardjati (2005:23) soal cerita merupakan soal matematika yang dinyatakan dalam bentuk cerita. Sedangkan menurut Budhi (2006:22) soal cerita adalah soal yang berbentuk cerita tentang sesuatu hal yang berkaitan dengan kehidupan sehari-hari. Menurut Hamdani (2008:5) dalam menyelesaikan soal cerita terlebih dahulu siswa harus memahami maksud dari soal tersebut. Kemudian baru memisahkan dan mengungkapkan apa yang diketahui, ditanya, dan penyelesaian soal cerita yaitu mentransformasikan bahasa verbal menjadi kalimat matematika.

Agar soal cerita dapat diselesaikan dengan baik diperlukan suatu pendekatan pembelajaran yang dapat meningkatkan hasil belajar siswa. Menurut Subana dan Sunarti (2000:20) "Pendekatan pembelajaran mempunyai pengaruh besar terhadap hasil yang diharapkan". Salah satu pendekatan pembelajaran yang dapat digunakan dalam pembelajaran soal cerita adalah pendekatan Contextual Teaching and Learning (CTL). Menurut Nurhadi (2003:11) pendekatan CTL bertujuan mengintegrasikan ide matematika ke dalam konteks kehidupan nyata dengan harapan siswa dapat memahami apa yang dipelajarinya dengan baik dan mudah. Menurut Kunandar (2008:293) "Pendekatan CTL adalah konsep belajar yang beranggapan bahwa siswa akan belajar lebih baik jika lingkungan diciptakan secara alamiah". Artinya belajar akan lebih bermakna jika siswa bekerja dan mengalami sendiri apa yang dipelajarinya, bukan sekedar mengetahuinya. Sedangkan menurut Wina (2008:225) pendekatan CTL adalah suatu pendekatan pembelajaran yang menekankan kepada proses keterlibatan siswa secara penuh untuk dapat menemukan materi yang dipelajari. Materi tersebut kemudian dihubungkan dengan situasi kehidupan nyata sehingga mendorong siswa untuk dapat menerapkannya dalam kehidupan sehari-hari.

Menurut Mulyasa (2008:103) pendekatan CTL mempunyai kelebihan yaitu memungkinkan proses pembelajaran yang tenang dan menyenangkan. Hal ini karena proses pembelajaran dilakukan secara alamiah sehingga siswa dapat mempraktekkan secara langsung apa-apa yang dipelajarinya. Selain itu pembelajaran dengan pendekatan CTL akan menambah semangat dan kreativitas siswa. Karena masalah yang dihadapkan kepada siswa adalah masalah yang ada di lingkungan dan akan berguna di kehidupan siswa tersebut. Menurut Nurhadi (2003:5) pendekatan CTL juga mempunyai manfaat, yaitu siswa dapat memecahkan masalah yang dihadapi dalam kehidupannya sebagai anggota keluarga dan masyarakat. Karena materi yang diberikan kepada siswa adalah masalah-masalah yang ada di lingkungannya.

Dari observasi masih banyak siswa yang kurang mengerti dalam menyelesaikan soal cerita tentang keliling persegi dan persegi panjang. Siswa kurang memahami maksud dari soal cerita. Sehingga tidak bisa membedakan mana yang diketahui, ditanya, dan penyelesaian dari soal cerita tersebut. Hal ini dapat dilihat dari hasil belajar soal cerita siswa yang masih dibawah KKM yaitu dengan rata-rata 67,24. Sedangkan mata pelajaran yang lain rata-ratanya lebih tinggi dibandingkan matematika. Berdasarkan hasil observasi faktor yang menyebabkan rendahnya nilai 
siswa adalah: pertama, guru hanya memberikan soal-soal yang ada di dalam buku paket tanpa mengaitkannya dengan kehidupan sehari-hari siswa. Kedua, guru masih menggunakan metode konvensional, yaitu metode ceramah dan bersifat monoton dalam pembelajaran.

Menurut Manan (dalam Megawati, 2004:10) pembelajaran matematika secara konvensional siswa diposisikan sebagai orang yang tidak tahu apa-apa. Siswa hanya menunggu dan menyerap apa yang diberikan guru, akibatnya siswa pasif dan guru menjadi aktif. Sedangkan guru hanya mentransfer pengetahuan kepada siswa tanpa memperhitungkan apakah ilmu yang ditransfer itu dapat diterima oleh siswa atau tidak, sehingga tujuan pembelajaran tidak tercapai dengan baik. Berdasarkan permasalahan yang telah diuraikan, maka peneliti tertarik untuk melakukan penelitian tentang "Upaya Meningkatkan Hasil Belajar Matematika Soal Cerita Melalui Pendekatan Contextual Teaching and Learning (CTL) pada Siswa Kelas III UPT. SD Negeri 21 Limo Kaum.

Berdasarkan latar belakang yang telah diuraikan, maka secara umum yang menjadi rumusan masalahnya adalah "Bagaimanakah Peningkatkan Hasil Belajar Matematika Soal Cerita Melalui Pendekatan Contextual Teaching and Learning (CTL) pada Siswa Kelas III UPT. SD Negeri 21 Limo Kaum. Masalah tersebut dapat peneliti rinci sebagai berikut: 1) Bagaimanakah rencana pembelajaran yang dapat meningkatkan hasil belajar Matematika soal cerita melalui pendekatan Contextual Teaching and Learning (CTL) pada siswa kelas III UPT. SD Negeri 21 Limo Kaum? 2) Bagaimanakah pelaksanaan pembelajaran yang dapat meningkatkan hasil belajar Matematika soal cerita melalui pendekatan Contextual Teaching and Learning (CTL) pada siswa kelas III UPT. SD Negeri 21 Limo Kaum? 3) Bagaimanakah peningkatan hasil belajar Matematika soal cerita melalui pendekatan Contextual Teaching and Learning (CTL) pada siswa kelas III UPT. SD Negeri 21 Limo Kaum?

\section{B. Metodologi Penelitian}

Penelitian ini dilakukan di UPT. SD Negeri 21 Limo Kaum.Kecamatan Lima Kaum. Kabupaten Tanah Datar.Lokasi ini dipilih sebagai tempat penelitian dengan pertimbangkan sebagai berikut. Pertama, guru cendrung menggunakan model pembelajaran konvensional, tanpa menekankan pemahaman konsep matematika. Kedua, belum pernah dilaksanakannya pembelajaran yang menggunakan pendekatan CTL dalam menyelesaikan soal cerita pada UPT. SD Negeri 21 Limo Kaum.Kecamatan Lima Kaum. Kabupaten Tanah Datar. Ketiga, siswa menganggap bahwa pelajaran soal cerita tidak menarik, membosankan, dan sulit dipahami, serta tidak ada kaitannya dengan kehidupan sehari-hari. Penelitian tindakan kelas ini dilakukan pada siswa kelas III UPT. SD Negeri 21 Limo Kaum.Kecamatan Lima Kaum. Kabupaten Tanah Datar. Jumlah siswanya yaitu 29 orang, 16 orang laki-laki dan 13 orang perempuan. Peneliti mengambil subjek penelitian di kelas III karena pembelajaran soal cerita tentang keliling persegi dan persegi panjang merupakan permasalahan yang terdapat pada siswa kelas III UPT. SD Negeri 21 Limo Kaum.Kecamatan Lima Kaum. Kabupaten Tanah Datar Adapun yang terlibat dalam penelitian ini adalah: Peneliti sebagai guru praktisi pada kelas III UPT. SD Negeri 21 Limo Kaum.Kecamatan Lima Kaum. Kabupaten Tanah Datar. Satu orang pengamat yaitu teman sejawat (Ibu Restuti.HR, S.Pd.SD). Pendekatan yang digunakan dalam penelitian ini adalah pendekatan kualititaf. Pendekatan ini berkenaan dengan perbaikan atau peningkatan proses pembelajaran pada suatu kelas. Jenis penelitian yang dilakukan merupakan penelitian tindakan kelas (action research) dibidang EISSN 2657-0289 $\quad$ Lembaga Penelitian dan Penerbitan Hasil Penelitian Ensiklopedia 89 
pendidikan dan pembelajaran matematika. Menurut Wardhani (2007:1.4) penelitian tindakan kelas adalah penelitian yang dilakukan oleh guru di dalam kelasnya sendiri dengan tujuan untuk memperbaiki kinerjanya sebagai guru, sehingga hasil belajar siswa meningkat. Sedangkan menurut Kunandar (2008:44) penelitian tindakan kelas adalah penelitian yang dilakukan oleh guru yang sekaligus sebagai peneliti di kelasnya atau bersama-sama dengan orang lain (kolaborasi). Penelitian dilakukan dengan jalan merancanag, melaksanakan, dan merefleksikan tindakan secara kolaboratif dan partisipatif yang bertujuan unutk memperbaiki proses pembelajaran di kelas melalui suatu tindakan dalam suatu siklus.

\section{Hasil dan Pembahasan}

Deskripsi Kondisi Awal. Dalam menyelesaikan soal cerita, siswa langsung mencari yang diketahui dan menyelesaikannya, tanpa membuat kalimat matematika. Kesulitan dalam memahami soal cerita dan membuat kalimat matematika akan berakibat kesulitan siswa dalam menyelesaikan soal cerita matematika

\section{Tabel Kondisi Awal Hasil Belajar Siswa}

\begin{tabular}{|c|c|c|c|c|c|}
\hline \multirow[b]{2}{*}{ No } & \multirow[b]{2}{*}{ Nama Peserta Didik } & \multirow[b]{2}{*}{ KKM } & \multirow[b]{2}{*}{ Nilai } & \multicolumn{2}{|c|}{ Ketuntasan } \\
\hline & & & & Ya & Tidak \\
\hline 1 & Abelia Altha Funisa & 75 & 40 & & $\sqrt{ }$ \\
\hline 2 & Afif Hilmi & 75 & 20 & & $\sqrt{ }$ \\
\hline 3 & Aisyah Putri & 75 & 80 & $\sqrt{ }$ & \\
\hline 4 & Alif Prima & 75 & 40 & & $\sqrt{ }$ \\
\hline 5 & Alifah Farras Wiranata & 75 & 60 & & $\sqrt{ }$ \\
\hline 6 & Andhika Pratama & 75 & 80 & $\sqrt{ }$ & \\
\hline 7 & Andro Putra Prasetya & 75 & 40 & & $\sqrt{ }$ \\
\hline 7 & Andro Putra Prasetya & 75 & 100 & $\sqrt{ }$ & \\
\hline 8 & Aulia Khairunisa & 75 & 60 & & $\sqrt{ }$ \\
\hline 9 & Brama Admirus & 75 & 80 & $\sqrt{ }$ & \\
\hline 10 & Chasandra Dwijayanti & 75 & 60 & & $\sqrt{ }$ \\
\hline 11 & Dafa Ihram Azami & 75 & 40 & & $\sqrt{ }$ \\
\hline 12 & Dini Fitri Liani & 75 & 80 & $\sqrt{ }$ & \\
\hline 13 & Fadly Habbibi & 75 & 80 & $\sqrt{ }$ & \\
\hline 14 & Indah Zahratul Adha & 75 & 80 & $\sqrt{ }$ & \\
\hline 15 & Kafatul Husein & 75 & 80 & $\sqrt{ }$ & \\
\hline 16 & Luthfiana Nur Alifa & 75 & 80 & $\sqrt{ }$ & \\
\hline 17 & Malaikha Sahira & 75 & 60 & & $\sqrt{ }$ \\
\hline 18 & Miftahul Qanitah & 75 & 80 & $\sqrt{ }$ & \\
\hline 19 & Muhammad FilArdy & 75 & 40 & & $\sqrt{ }$ \\
\hline 20 & Muhammad Ghenta Fahrozi & 75 & 60 & & $\sqrt{ }$ \\
\hline 21 & Muhammad Syukri & 75 & 20 & & $\sqrt{ }$ \\
\hline 22 & Mulya Iqbal Asrazi & 75 & 80 & $\sqrt{ }$ & \\
\hline 23 & Najwa Puti Ariza & 75 & 80 & $\sqrt{ }$ & \\
\hline 24 & Nazhifah Fikri Yani & 75 & 60 & & $\sqrt{ }$ \\
\hline 25 & Ochinawa Rometa & 75 & 80 & $\sqrt{ }$ & \\
\hline 26 & Restu Dwi Putri & 75 & 40 & & $\sqrt{ }$ \\
\hline 27 & Rezky Nofrizal & 75 & 80 & $\sqrt{ }$ & \\
\hline 28 & Sergio Alfares & 75 & 60 & & $\sqrt{ }$ \\
\hline 29 & Yustisian Hazig & 75 & 40 & & $\sqrt{ }$ \\
\hline \multicolumn{3}{|c|}{ Jumlah } & 1840 & 13 & 16 \\
\hline \multicolumn{3}{|c|}{ Nilai rata-rata siswa } & 63,45 & & \\
\hline \multicolumn{4}{|c|}{ Presentase } & $44.83 \%$ & $55,17 \%$ \\
\hline
\end{tabular}

Dari tabel diatas terlihat bahwa hasil belajar siswa masih rendah. Karena siswa yang tuntas dalam belajar hanya 13 orang siswa atau hanya 44,83\%, sedangkan jumlah siswa yang tidak tuntas dalam belajar berjumlah 16 orang siswa atau sekitar 55,17\%, 
selain itu nilai rata-rata siswa 63,45 sedangkan KKM yang telah ditentukan oleh guru adalah 75 artinya tingkat ketuntasan dalam belajar siswa masih rendah dari yang seharusnya yaitu $75 \%$. Dari hasil yang diperoleh diatas, peneliti mulai melakukan penelitian tindakan kelas Melalui Pendekatan Contextual Teaching and Learning (CTL guna meningkatkan hasil belajar siswa pada Mata Pelajaran matematika di kelas III UPT.SD Negeri 21 Limo Kaum.

Deskripsi Hasil Penelitian Siklus 1. Pelaksanaan penelitian dalam upaya meningkatkan hasil belajar Matematika siswa kelas III UPT. SD Negeri 21 Limo Kaum dilaksanakan dalam dua siklus. Masing-masing siklus dilaksanakan sesuai dengan standar kompetensi dan kompetensi dasar mata pelajaran Matematika. Jumlah skor yang diperoleh siswa dalam melaksanakan pembelajaran dengan menggunakan pendekatan CTL adalah 26 dan skor maksimal 36. Dengan demikian persentase rataratanya adalah $72,2 \%$. Hal ini menunjukkan bahwa taraf keberhasilan siswa dalam menggunakan pendekatan CTL berada pada kategori cukup. Keberhasilan siswa dalam hasil pembelajaran soal cerita tentang keliling persegi dan persegi panjang dilihat dari segi hasil belajar yang dicapai pada siklus I mempunyai rata-rata 74,48. Berdasarkan taraf rata-rata keberhasilan kemampuan berada pada taraf cukup. Hasil belajar yang dicapai siswa dapat dilihat pada tabel berikut ini:

Tabel Hasil Belajar Siswa Pada Siklus I

\begin{tabular}{|c|c|c|c|c|c|}
\hline \multirow[b]{2}{*}{ No } & \multirow[b]{2}{*}{ Nama Peserta Didik } & \multirow[b]{2}{*}{ KKM } & \multirow[b]{2}{*}{ Nilai } & \multicolumn{2}{|c|}{ Ketuntasan } \\
\hline & & & & Tuntas & Tidak \\
\hline 1 & Abelia Altha Funisa & 75 & 40 & & $\sqrt{ }$ \\
\hline 2 & Afif Hilmi & 75 & 40 & & $\sqrt{ }$ \\
\hline 3 & Aisyah Putri & 75 & 80 & $\sqrt{ }$ & \\
\hline 4 & Alif Prima & 75 & 60 & & $\sqrt{ }$ \\
\hline 5 & Alifah Farras Wiranata & 75 & 80 & $\sqrt{ }$ & \\
\hline 6 & Andhika Pratama & 75 & 80 & $\sqrt{ }$ & \\
\hline 7 & Andro Putra Prasetya & 75 & 60 & & $\sqrt{ }$ \\
\hline 8 & Aulia Khairunisa & 75 & 100 & $\sqrt{ }$ & \\
\hline 9 & Brama Adminus. & 75 & 80 & $\sqrt{ }$ & \\
\hline 10 & Chasandra Dwijayanti & 75 & 80 & $\sqrt{ }$ & \\
\hline 11 & Dafa Ihram Azami & 75 & 80 & $\sqrt{ }$ & \\
\hline 12 & Dini Fitri Liani & 75 & 60 & & $\sqrt{ }$ \\
\hline 13 & Fadly Habbibi & 75 & 100 & $\sqrt{ }$ & \\
\hline 14 & Indah Zahratul Adha & 75 & 80 & $\sqrt{ }$ & \\
\hline 15 & Kafatul Husein & 75 & 80 & $\sqrt{ }$ & \\
\hline 16 & Luthfiana Nur Alifa & 75 & 80 & $\sqrt{ }$ & \\
\hline 17 & Malaikha Sahira & 75 & 80 & $\sqrt{ }$ & \\
\hline 18 & Miftahul Qanitah & 75 & 80 & $\sqrt{ }$ & \\
\hline 19 & Muhammad FilArdy & 75 & 80 & $\sqrt{ }$ & \\
\hline 20 & Muhammad Ghenta Fahrozi & 75 & 60 & & $\sqrt{ }$ \\
\hline 21 & Muhammad Syukri & 75 & 80 & $\sqrt{ }$ & \\
\hline 22 & Mulya Iqbal Asrazi. & 75 & 40 & & $\sqrt{ }$ \\
\hline 23 & Naiwa Puti Ariza & 75 & 80 & $\sqrt{ }$ & \\
\hline 24 & Nazhifah Fikri Yani & 75 & 100 & $\sqrt{ }$ & \\
\hline 25 & Ochinawa Rometa & 75 & 80 & $\sqrt{ }$ & \\
\hline 26 & Restu Dwi Putri & 75 & 80 & $\sqrt{ }$ & \\
\hline 27 & Rezky Nofrizal & 75 & 60 & & $\sqrt{ }$ \\
\hline 28 & Sergio Alfares & 75 & 80 & $\sqrt{ }$ & \\
\hline 29 & Yustisian Hazig & 75 & 80 & $\sqrt{ }$ & \\
\hline \multicolumn{3}{|c|}{ Jumlah } & 2160 & 21 & 8 \\
\hline & rata-rata siswa & & 74,48 & & \\
\hline \multicolumn{4}{|c|}{ Presentase } & $72,41 \%$ & $27,59 \%$ \\
\hline
\end{tabular}

Hasil dari tabel diatas diketahui bahwa nilai rata-rata siswa masih rendah dan belum memenuhi Kriteria Keberhasilan Minimal (KKM). Hal ini terlihat dari rendahnya nilai rata-rata yang diperoleh siswa pada siklus I yaitu 74,48 jumlah siswa yang memperoleh nilai yang $\geq 75$ hanya 21 orang atau $72,41 \%$ dari jumlah siswa yang 
memperoleh nilai dan siswa yang belum berhasil sebanyak 8 orang atau 27,59\% dari jumlah siswa keseluruhan, artinya tindakan yang diberikan pada siklus I belum mencapai Indikator Kriteria Kelulusan Siswa pada kelas III mata pelajaran matematika di UPT.SD Negeri 21 Limo Kaum, oleh karena itu tindakan harus dilanjutkan pada siklus II.

\section{Diagram Hasil Belajar Siswa Pada Siklus 1.}

Selain hasil pengamatan menggunakan lembaran observasi yang dilakukan pengamat, ada juga catatan lapangan yang merupakan catatan penting peneliti dalam suatu rangkaian kegiatan pembelajaran yang perlu diperhatikan dari aktiviatas guru dan siswa. Hasil catatan lapangan dapat disimpulkan sebagai berikut: 1) Siswa sudah mulai bisa berdiskusi dalam kelompok, namun keaktifan siswa masih kurang; 2) Saat presentasi, siswa masih malu-malu untuk menanggapi hasil pekerjaan temannya; 3) Sebagian besar siswa sudah mengerti dengan langkah-langkah pemecahan masalah; dan 4) Dalam pembagian kelompok siswa sudah mulai agak tenang, karena siswa duduk berdasarkan kelompok pada pertemuan I dan tidak memakan waktu yang lama.

Berdasarkan hasil temuan pada siklus I ini, dapat disimpulkan bahwa aktivitas peneliti dan siswa belum mencapai kategori keberhasilan yang ditetapkan, karena pemahaman siswa terhadap langkah penyelesaian soal cerita masih kurang dan keaktifan siswa masih kurang, sehingga komponen CTL belum berjalan sesuai dengan yang diharapkan. Hal ini disebabkan karena guru masih baru dalam hal pembelajaran melalui pendekatan CTL, bimbingan guru terhadap siswa masih kurang dalam pelaksanaan pembelajaran, siswa belum terbiasa dengan pembelajaran melalui pendekatan CTL, serta siswa belum terbiasa belajar secara berkelompok. Maka, perlu dilanjutkan pada siklus berikutnya. Pelaksanaan siklus II diharapkan dengan memperhatikan hal-hal sebagai berikut: 1) Peneliti harus membimbing siswa agar mampu melaksanakan langkah-langkah penyelesaian soal cerita terutama membuat kalimat matematika dengan benar; dan 2) Peneliti memberikan reward kepada siswa yang mampu menjawab pertanyaan yang peneliti berikan dengan benar. Selain itu peneliti juga harus memperhatikan siswa dalam bekerja dalam kelompoknya, agar semuanya terlibat aktif dalam kelompoknya.

\section{Deskripsi Penelitian Siklus II.}

Berdasarkan hasil refleksi pada tindakan siklus I, maka ditetapkan pelaksanaan siklus II. Pelaksanaan siklus II lebih ditekankan pada pemahaman siswa terhadap materi dan langkah-langkah CTL serta meningkatkan keaktifan siswa sehingga siswa dapat menyelesaikan soal cerita dengan baik. Kegiatan yang dilakukan pada siklus II meliputi tahap perencanaan, pelaksanaan, observasi dan refleksi.

Hasil observasi yang dilakukan pengamat terhadap aktivitas siswa, yang menggunakan pendekatan CTL.Berdasarkan hasil observasi yang dilakukan pengamat terhadap aktivitas siswa dalam menggunakan pendekatan CTL, jumlah skor yang diperoleh adalah 32 dan skor maksimal adalah 36. Dengan demikian persentase skor rata-rata adalah $88,9 \%$. Hal ini menunjukkan bahwa taraf keberhasilan siswa dalam menggunakan pendekatan CTL berada dalam kategori baik. Selain itu ada beberapa catatan lapangan yang didapat pada pertemuan ke II ini yaitu:

1. Siswa mampu melakukan presentasi dan siswa lain sudah bisa menaggapi.

2. Siswa kelihatan aktif dalam kelompoknya dan terjadi masyarakat belajar dalam kelompok .

3. Suasana kelas tenang dan siswa bekerjasama aktif dalam kelompok. 
4. Siswa sudah memahami langkah pemecahan masalah dengan baik. Hal ini terlihat dari hasil belajar siswa yang meningkat.

5. komponen CTL sudah terlaksana dengan baik.

Sedangkan hasil pembelajaran penyelesaian soal cerita melalui pendekatan CTl yang dicapai siswa pada siklus II dapat dilihat dari tabel berikut:

Tabel Hasil Pembelajaran Soal Cerita melalui Pendekatan CTL pada Siklus II

\begin{tabular}{|c|c|c|c|c|c|}
\hline \multirow[b]{2}{*}{ No } & \multirow[b]{2}{*}{ Nama Peserta Didik } & \multirow[b]{2}{*}{ KKM } & \multirow[b]{2}{*}{ Nilai } & \multicolumn{2}{|c|}{ Ketuntasan } \\
\hline & & & & $\mathrm{Ya}$ & Tidak \\
\hline 1 & Abelia Altha Funisa & 75 & 60 & & $\sqrt{ }$ \\
\hline 2 & Afif Hilmi & 75 & 40 & & $\sqrt{ }$ \\
\hline 3 & Aisyah Putri & 75 & 80 & $\sqrt{ }$ & \\
\hline 4 & Alif Prima & 75 & 60 & & $\sqrt{ }$ \\
\hline 5 & Alifah Farras Wiranata & 75 & 80 & $\sqrt{ }$ & \\
\hline 6 & Andhika Pratama & 75 & 80 & $\sqrt{ }$ & \\
\hline 7 & Andro Putra Prasetya & 75 & 80 & $\sqrt{ }$ & \\
\hline 8 & Aulia Khairunisa & 75 & 100 & $\sqrt{ }$ & \\
\hline 9 & Brama Admirus & 75 & 80 & $\sqrt{ }$ & \\
\hline 10 & Chasandra Dwijayanti & 75 & 80 & $\sqrt{ }$ & \\
\hline 11 & Dafa Ihram Azami & 75 & 80 & $\sqrt{ }$ & \\
\hline 12 & Dini Fitri Liani & 75 & 80 & $\sqrt{ }$ & \\
\hline 13 & Fadly Habbibi & 75 & 100 & $\sqrt{ }$ & \\
\hline 14 & Indah Zahratul Adha & 75 & 100 & $\sqrt{ }$ & \\
\hline 15 & Kafatul Husein & 75 & 80 & $\sqrt{ }$ & \\
\hline 16 & Luthfiana Nur Alifa & 75 & 100 & $\sqrt{ }$ & \\
\hline 17 & Malaikha Sahira & 75 & 100 & $\sqrt{ }$ & \\
\hline 18 & Miftahul Qanitah & 75 & 80 & $\sqrt{ }$ & \\
\hline 19 & Muhammad FilAndy, & 75 & 80 & $\sqrt{ }$ & \\
\hline 20 & Muhammad Ghenta Fahrozi & 75 & 80 & $\sqrt{ }$ & \\
\hline 21 & Muhammad Syukri & 75 & 80 & $\sqrt{ }$ & \\
\hline 22 & Mulya Iqbal Asrazi & 75 & 40 & & $\sqrt{ }$ \\
\hline 23 & Naiwa Puti_Ariza. & 75 & 80 & $\sqrt{ }$ & \\
\hline 24 & Nazhifah Fikri Yani & 75 & 100 & $\sqrt{ }$ & \\
\hline 25 & Qchinawa Rometa & 75 & 80 & $\sqrt{ }$ & \\
\hline 26 & Restu Dwi Putri & 75 & 100 & $\sqrt{ }$ & \\
\hline 27 & Rezky Nofrizal & 75 & 80 & $\sqrt{ }$ & \\
\hline 28 & Sergio Alfares & 75 & 80 & $\sqrt{ }$ & \\
\hline 29 & Yustisian Hazig & 75 & 80 & $\sqrt{ }$ & \\
\hline \multicolumn{2}{|c|}{ Jumlah } & & 2340 & 25 & 4 \\
\hline \multicolumn{2}{|c|}{ Nilai rata-rata siswa. } & & 80,69 & & \\
\hline \multicolumn{4}{|c|}{ Presentase } & $86,21, \%$ & $13,79 \%$ \\
\hline
\end{tabular}

Hasil dari tabel diatas dapat kita lihat bahwa hasil belajar siswa pada siklus II sudah mengalami penigkatan. Ini dapat diketahui dari siklus I yang diikuti 29 orang siswa, nilai rata-rata yang diperoleh siswa meningkat dari 74,48 pada siklus I menjadi 80,69 pada siklus II. Siswa yang memperoleh nilai $\geq 75$ sebanyak 25 orang siswa, itu berarti keberhasilan siswa mencapai $86,21 \%$ siswa yang belum berhasil 4 orang siswa atau $13,79 \%$. Angka ini telah menunjukkan bahwa hasil belajar siswa pada kelas III. 
mata pelajaran matematika di UPT.SD Negeri 21 Limo Kaum telah mencapai indikator kriteria kelulusan siswa. oleh karena itu, penelitian ini tidak perlu dilanjutkan lagi.

\section{Diagram Hasil Belajar Siswa Pada Siklus II}

Berdasarkan hasil belajar tindakan setelah pembelajaran pada pertemuan I dan II siklus II, hasil catatan lapangan, maka selama pelaksanaan tindakan pertemuan I dan II siklus II diperoleh hasil sebagai berikut: a) Pembelajaran sudah kelihatan komponen CTL ditiap-tiap langkahnya; b) Interaksi kelas sudah bagus, yaitu banyak siswa yang mau maju ke depan untuk menuliskan atau menyampaikan hasil pekerjaannya. Siswa kelihatannya mau bertanya, siswa mau mengeluarkan pendapat. Suasana kelas nampak hidup, dan diskusi kelompok dan diskusi kelas berjalan lancar; dan c) Skor akhir tindakan menunjukkan peningkatan yang cukup tinggi. Siswa telah mencapai tingkat ketuntasan yang ditetapkan. Dari refleksi tersebut di atas, maka disimpulkan pembelajaran siklus II telah berjalan dengan yang diharapkan. Berdasarkan hasil belajar siswa dan hasil observasi, hasil belajar siswa telah mencapai rata-rata 80,69 dan secara klasikal siswa telah mencapai ketuntasan $86.21 \%$. Selain itu keaktifan siswa pada siklus II telah meningkat.maka penelitian ini sudah dapat dikatakan berhasil

\section{Pembahasan Hasil}

Berdasarkan hasil penelitian yang dikemukakan di atas, berikut ini akan disajikan pembahasan tentang pembelajaran soal cerita tentang persegi dan persegi panjang melalui pendekatan CTL dan penilaiannya.

Pembahasan siklus I. Berdasarkan hasil catatan di lapangan dan diskusi antara peneliti dengan teman sejawat, penyebab dari adanya siswa yang belum dapat menyelesaikan soal cerita yang berkaitan dengan persegi dan persegi panjang adalah karena rendahnya pemahaman siswa terhadap soal yang diberikan dan siswa masih kesulitan dalam menemukan kalimat matematika dari soal cerita. Selain itu, siswa terbiasa belajar sendiri-sendiri (tidak berkelompok) sehingga masyarakat belajar belum tercipta. Hal ini mengakibatkan siswa yang berkemampuan rendah mengalami kesulitan dalam menyelesaikan soal cerita terutama membuat kalimat matematika. Berikut ini akan dibahas lebih lanjut tentang hasil yang ditemukan di lapangan tentang pembelajaran soal cerita melalui pendekatan CTL. Dalam menentukan keefektifan belajar melalui pendekatan CTL terhadap materi menyelesaikan soal cerita tentang keliling persegi dan persegi panjang adalah peningkatan hasil belajar siswa. Berdasarkan hasil yang dicapai dapat dinyatakan bahwa siswa telah belajar menyelesaikan soal cerita melalui pendekatan CTL sesuai dengan yang diterapkan. Ini dapat kita lihat bahwa hasil belajar sudah sesuai dengan apa yang diharapkan. Pada pembelajaran soal cerita melalui pendekatan CTL, siswa belajar dalam kelompok yang memiliki keampuan berbeda, supaya antara sesama anggota kelompok saling membantu untuk menyelesaikan tugas bersama. Hal lain yang menunjang hasil pembelajaran sesuai dengan yang diharapkan adalah Ibu Restuti.HR, S.Pd.SD sebagai observer memberikan masukan dalam peningkatan hasil pembelajaran pada siklus dua. Yang lebih mendukung peningkatan hasil belajar sesuai dengan yang diharapkan adalah jumlah siswa kelas III UPT. SD Negeri 21 Limo Kaum yang berjumlah 29 orang dengan kelompok yang terdiri dari lima kelompok sehingga mudah memantaunya. Dari analisis penelitian siklus I nilai rata-rata kelas baru mencapai 74,48 Maka direncanakan untuk melakukan perbaikan pada pembelajaran berikutnya atau perbaikan selama proses pembelajaran pada siklus II. Pada siklus II nantinya guru 
harus memperhatikan kukurangan-kekurangan selama proses pembelajaran pada siklus I.

Pembahasan Siklus II. Berdasarkan hasil yang dicapai dapat dinyatakan bahwa siswa telah belajar melalui pendekatan CTL sesuai dengan yang diterapkan. Ini dapat dilihat bahwa bahwa hasil belajar sudah sesuai dengan apa yang diharapkan. Karena dalam belajar melalui pendekatan CTL siswa belajar sendiri dalam kelompok yang memiliki kemampuan berbeda. Pada siklus II siswa sudah nampak aktif dan bersemangat dalam belajar. Siswa sudah memahami cara belajar menyelesaikan soal cerita melalui pendekatan CTL. Pada silkus II ini peneliti juga mmeberikan tes. Dari analisis penelitian siklus II nilai rata-rata siswa sudah mencapai 80,69. Berdasarkan hasil pengamatan selama pelaksanaan siklus II, maka yang diperoleh dari pelaksanaan siklus II sudah mencapai target yang diinginkan dan peneliti sudah dikatakan berhasil dalam usaha meningkatkan hasil belajar matematika siswa kelas III UPT. SD Negeri 21 Limo Kaum Kecamatan Lima Kaum. Kabupaten Tanah Datar.

\section{Penutup}

Dari paparan dan hasil penelitian dan pembahasan dalam Bab IV, simpulan yang dapat diambil dari penelitian ini adalah sebagai berikut: 1) Rencana pelaksanaan pembelajaran soal cerita melalui pendekatan CTL menggunakan tiga tahapan pembelajaran, yaitu tahap awal, tahap inti dan tahap akhir. Pada tahap awal kegiatannya yaitu memberikan motivasi, menyampaikan tujuan pembelajaran, dan appersepsi. Pada tahap inti dilaksanakan kegiatan pembelajaran dengan langkah pendekatan CTL, serta pada tahap akhir kegiatan siswa yaitu menyimpulkan pembelajaran dan pemberian PR; 2) Pelaksanaan pembelajaran soal cerita melalui Pendekatan CTL terdiri dari 7 langkah pendekatan CTL dan dikombinasikan dengan langkah-langkah memyelesaikan soal cerita. Pembelajaran menggunakan pendekatan CTL dibagi atas tiga tahapan yaitu tahap awal, tahap inti, dan tahap akhir. Pada tahap awal dilaksanakan kegiatan pengaktifan pengetahuan awal siswa, menyampaikan tujuan pembelajaran, dan appersepsi. Pada tahap inti dilaksanakan langkah-langkah CTL yaitu konstruktivisme, inkuiri, bertanya, masyarakat belajar, pemodelan, refleksi, dan penilaian yang sebenarnya. Pada tahap akhir kegiatan siswa diarahkan untuk menyimpulkan penbelajaran dan memberikan tes akhir; dan 3) Dilihat dari hasil tes akhir siklus 1, siswa memperoleh nilai rata-rata menjadi 74,48. Dan tes akhir siklus II rata-rata siswa meningkat menjadi 780.69. Jadi dilihat dari rata-rata yang diperoleh siswa dengan menggunakan pendekatan CTL hasil pembelajaran siswa dapat ditingkatkan.

\section{Daftar Pustaka}

Antonius cahyo Prihandoko. 2005. Pemahaman dan Penyajian Konsep Matematika Secara Benar dan Menarik. Jakarta: Depdiknas

Budhi Setyono. 2006. Meningkatkan kemampuan Menyelesaikan Soal Cerita Pokok Bahasan Pengukuran dengan metode Problem Solving. Tersedia dalam http//www. Com. Online.

Cholis Sadijah.1999. Pendidikan Matematika II. Jakarta: Depdikbud

Depdiknas. 2006. Kurikulum Tingkat Satuan Pendidikan (KTSP). Jakarta: Depdiknas

Dian Rahmana. 2009. Penggunaan Pendekatan Kontekstual dalam Pembelajaran di $S D$. Padang: UNP (TA tidak dipublikasikan)

Hamdani. 2008. Memahami Masalah Soal Cerita Matematika. Tersedia dalam http//www. Com. Online. 
IGAK Wardhani,dkk. 2007. Penelitian Tindakan kelas. Jakarta : Universitas Terbuka Joko Subagyo. 2006. Metode Penelitian dalam Teori dan Praktek. Jakarta: Pt Rineka Cipta

Khafid Suyati. 2006. Matematika Penekanan pada Berhitung. Jakarta: Erlangga

Kunandar. 2008. Guru Profesional Implementasi Kurikulum Tingkat Satuan Pendidikan (KTSP) dan Sukses dalam sertifikasi Guru. Jakarta: PT Raja Grafindo Persada

Masnur Muslich. 2007. KTSP (Kurikulum Tingkat Satuan Pendidikan) Dasar Pemahaman dan Pengembangan. Jakarta: Bumi Aksara

Megawati. 2004. Pembelajaran Melalui Pemecahan Realistik untuk Memahami Konsep SPL Dua Variabel Pada Siswa Kelas II SLTP Suppa. Malang: Universitas Negeri Malang (Tesis tidak dipublikasikan)

Mulyasa. 2008. Menjadi Guru Profesional Menciptakan Pembelajaran Aktif dan Kreatif. Bandung: PT Remaja Rosdakarya

Najib Sulhan. 2006. Pembangunan Karakter pada Anak Manajemen Pembelajaran Guru Menuju Sekolah Efektif. Surabaya: Surabaya Intelektual Club

Nasar. 2006. Merancang Pembelajaran Aktif dan Kontekstual. Jakarta: PT Gramedia Widiasarana Indonesia

Nurhadi. 2003. Pembelajaran Kontekstual (Contextual Teaching and Learning) dan Penerapannya dalam KBK. Malang: UNM

Oemar Hamalik. 2008. Proses Belajar Mengajar. Jakarta: Bumi Aksara

Ritawati Mahyuddin. 2008. Hand Out Mata Kuliah Metodologi Penelitian Tindakan Kelas. Padang: UNP

Sri Subarinah. 2006. Inovasi Pembelajaran Matematika di SD. Jakarta: Depdiknas

Subana dan Sunarti. 2000. Startegi Belajar Mengajar Bahasa Indonesia. Bandung: Pustaka Setia

Sumardjati. 2005. Meningkatkan Kemampuan Menyelesaikan Soal Cerita Pokok Bahasan Pecahan Melalui diskusi kelompok. Tersedia dalam http// www. Com. Online.

Sumiati dan Asra. 2007. Metode Pembelajaran. Bandung: CV Wacana Media

Vikto Pendrawarman. 2008. Peningkatan Hasil Belajar IPA Melalui Metode Discovery dalam Pembelajaran Perubahan Lingkungan di Kelas IV SD. Padang: UNP (Skripsi tidak dipublikasikan)

Wina Sanjaya.2008. Srategi Pembelajaran Berorientasi Standar Proses Pendidikan.Jakarta: Kencana Prenada Media Group 